\title{
ENTRE O ESPAÇO ABSTRATO \\ E O ESPAÇO DIFERENCIAL: \\ ocupaçóes urbanas em Belo Horizonte ${ }^{1}$
}

\section{BETWEEN ABSTRACT SPACE AND DIFFERENTIAL SPACE:}

URBAN OCCUPATIONS IN BELO HORIZONTE²

\author{
Camila Diniz Bastos A, B, E, F \\ Universidade Federal de Minas Gerais, Escola de Arquitetura, Belo Horizonte, MG, Brasil
}

Felipe Nunes Coelho Magalhấes A, B, E, F

Universidade Federal de Minas Gerais, Instituto de Geociências, Belo Horizonte, MG, Brasil

Guilherme Marinho Miranda A, B, E, F

Universidade Federal de Minas Gerais, Programa de Pós-Graduação em Geografia, Belo Horizonte, MG, Brasil

Harley Silva A, B, E, F

Universidade Federal de Minas Gerais, Centro de Desenvolvimento e Planejamento Regional, Belo Horizonte, MG, Brasil

João Bosco Moura Tonucci Filho A, B, E, F

Universidade Federal de Minas Gerais, Programa de Pós-Graduação em Geografia, Belo Horizonte, MG, Brasil

Mariana de Moura Cruz A, B, E, F

Universidade Federal de Minas Gerais, Programa de Pós-Graduação em Arquitetura e Urbanismo, Belo Horizonte, MG, Brasil

Rita de Cássia Lucena Velloso A, B, E, F

Universidade Federal de Minas Gerais, Escola de Arquitetura, Belo Horizonte, MG, Brasil

R E S U M O : O artigo aborda as ocupaçôes urbanas em Belo Horizonte a partir das formulaçôes de Henri Lefebvre sobre a produção do espaço e a vida cotidiana. Ao refletirmos sobre as experiências das ocupaçôes, buscamos enfatizar suas dimensões relacionais e processuais, atentando-nos à sua materialidade e ao seu cotidiano vivido. Para entender em que medida as ocupaçóes podem engendrar diferenciaçôes espaciais, circunscrevemos seu percurso histórico em Belo Horizonte segundo suas dinâmicas e tensôes, atentos às especificidades da produção do espaço nas mesmas. Discutimos também as contradições entre o privado e o comum quanto à propriedade da terra, ressaltando os modos pelos quais o espaço abstrato se reafirma nas ocupaçôes. Procuramos ressaltar as ocupaçôes como tensionadas entre o espaço abstrato e o diferencial, como uma prática espacial intermediária entre a dominação e a apropriação: espaço político contraditório, que atualiza o debate sobre a produção do espaço urbano no Brasil contemporâneo.

P A L A V R A S - C H A V E : ocupações urbanas; espaço diferencial; produção do espaço; vida cotidiana; Belo Horizonte; Henri Lefebvre.

Contribuição de cada autor/a: A. fundamentação teórico-conceitual e problematização; B. pesquisa de dados e análise estatística; C. elaboração de figuras e tabelas; D. fotos; E. elaboração e redação do texto; F. seleção das referências bibliográficas.

1 Este artigo é produto de debates, investigações compartilhadas e de um esforço de escrita coletiva no âmbito do Grupo de Estudos Henri Lefebvre (GEHL/UFMG). O GEHL/UFMG organizou-se desde 2003, fundado pelo Prof. Roberto Luís de Melo Monte-Mór (FACE/UFMG), com o propósito de estudar a obra de Henri Lefebvre, em especial a problemática urbana, nas diversas configurações que esse tema assume nos textos desse pensador. O GEHL reúne na Universidade Federal de Minas Gerais (UFMG) professores e estudantes de graduação e pósgraduação em economia, geografia, arquitetura e direito. Entre 2003 e 2015, em suas diversas formações, o GEHL vem participando dos Encontros da Associação Nacional de Pós-Graduação e Pesquisa em Planejamento Urbano e Regional (ENANPUR) por meio da organização de sessões livres junto a outros pesquisadores da obra lefebvriana no Brasil. Nos últimos anos (2015-2017), o GEHL tem atuado no sentido de articular a teoria lefebvriana aos processos de produção do espaço urbano brasileiro.

2 An English version of this article is being prepared by GEHL/UFMG and will be available for download in the group's Academia.edu profile: https://ufmg.academia.edu/GrupodeEstudosHenriLefebvre

DOI: https://doi.org/10.22296/2317-1529.2017v19n2p251 
A B S T R A C T : This article explores urban occupations in Belo Horizonte departing from Henri Lefebvre's formulations on the production of space and everyday life. As we reflect on the experiences of these occupations, we seek to emphasize their relational and processual dimensions, paying attention to their materiality and their lived everyday. In order to understand the extent to which occupations can engender spatial differentiations, we circumscribe their historical background in Belo Horizonte according to their dynamics and tensions, attentive to the specificities of their production of space. We also discuss the contradictions between the private and the commons in regards to the landed property, highlighting the ways in which abstract space is reaffirmed in occupations. We seek to accentuate urban occupations as tensioned between abstract and differential spaces, as an intermediate spatial practice between domination and appropriation: a contradictory political space, which updates the debate on the production of urban space in contemporary Brazil.

K E Y W O R D S : urban occupations; differential space; production of space; everyday life; Belo Horizonte; Henri Lefebvre.

\section{NTRODUÇÃO}

Um dos fenômenos mais disruptivos na metrópole brasileira nos últimos anos tem sido a explosão de ocupações urbanas - sob os mais variados modos de organização -, processo que se vincula a um contexto vicioso em que se combinam crescimento econômico, ampliação da renda e do crédito, expansão do mercado imobiliário, aumento vertiginoso do preço do solo e políticas ditas habitacionais que privilegiam mais os capitais imobiliários do que as necessidades de moradia dos pobres urbanos (MAGALHÃES; TONUCCI FILHO; SILVA, 2011). Na Região Metropolitana de Belo Horizonte (RMBH), hoje quase 15 mil famílias residem em mais de 20 ocupaçóes urbanas, segundo informaçóes de Morado Nascimento e Libânio (2016). Espontâneas e/ou organizadas por movimentos sociais com extensas redes de apoio, as ocupaçôes têm início por meio de açôes concentradas no tempo: em não mais de uma semana, um grupo de famílias se estabelece em terrenos vagos (públicos ou privados), para daí prosseguir à autoconstrução de residências e da infraestrutura básica.

Este artigo tem o intuito de propor um espaço de pensamento crítico sobre as ocupaçóes em Belo Horizonte (BH), especialmente - mas não exclusivamente - a partir de questóes que a obra do filósofo e sociólogo francês Henri Lefebvre (19011991) suscita às realidades brasileiras contemporâneas. Esses territórios ocupam hoje importante espaço nos debates e embates políticos locais, nos engajamentos de militantes e apoiadores, nas experimentaçôes práticas e cotidianas, na reflexão sobre as lutas pelo direito à cidade. Daí o desejo de problematizar e de interrogar criticamente uma realidade que, por vezes, nos parece tão próxima e transparente e, noutras ocasiôes, tão distante, quase inapreensível.

Procuramos, ao refletirmos sobre as experiências das ocupaçôes, enfatizar suas dimensóes relacionais e processuais, atentando à sua materialidade e ao seu cotidiano vivido, evitando entendimentos deterministas e finalísticos que só percebem nas ocupaçóes a desolação da miséria e da desigualdade ou a utopia de uma comunidade perfeita. Entre os extremos do niilismo e do romantismo de tais abordagens, coloca- 
mo-nos o desafio de analisar as ocupaçóes como dialeticamente tensionadas entre o espaço abstrato e o espaço diferencial teorizados por Lefebvre entre a dominação e a apropriação: nem um, nem outro, mas ambos ao mesmo tempo; um espaço contraditório, aberto e movente.

Apostando que há mundos diferentes para além de suas amarras e dos absurdos da repetição, nosso trabalho busca compreender as diferenças (gestos, percursos, ritmos, ciclos) que brotam com as ocupaçóes urbanas belo-horizontinas. Movidos pela possibilidade de encontrarmos, nessas ocupaçôes, o germe de um espaço diferencial, buscamos entrelaçar teoria e prática na tentativa de construir e de compreendê-las.

Podemos sustentar que as ocupaçôes urbanas produzem diferenciações espaciais? De que modo as práticas de ocupação da $\mathrm{RMBH}$ permitem atualizar o debate sobre a produção do espaço diferencial? Como engendrar a produção de um espaço diferencial a partir do cotidiano das ocupaçóes? Enfim, se "o caminho do 'concreto' passa pela negação ativa, teórica e prática: pelo contraprojeto, o contraplano”, como afirma Lefebvre (2000, p. 481, tradução nossa), "pela intervenção ativa e massiva dos 'interessados'”, que sentidos concretos do cotidiano das ocupaçóes nos levam a pensar em práticas do espaço diferencial?

Procuramos respostas concretas a tais indagações nas lutas e no cotidiano vivido dos moradores das ocupaçóes, assim como nos relatos daqueles envolvidos, direta ou indiretamente, nas ações de resistência e de construção coletiva das ocupaçôes.

$\mathrm{O}$ método dialético ${ }^{3}$ da presente abordagem consiste numa alternância entre formas qualitativas de pesquisa (entrevistas e observaçáo participante, principalmente) conduzidas pelos autores ao longo dos últimos anos em suas diversas frentes de trabalho, e as propostas de teorização, a partir de um grupo de leituras e discussóes da obra de Henri Lefebvre.

O artigo está organizado em seis sessões. Depois da introdução, na segunda sessão, trazemos a problemática da produção do espaço a partir das reflexóes de Lefebvre, buscando enfatizar os sentidos possíveis da diferenciação espacial em meio às contradiçóes do espaço abstrato. A seguir, na terceira sessão, circunscrevemos o percurso histórico das ocupações na RMBH segundo suas dinâmicas e tensões, em busca de suas especificidades. Na quarta sessáo, abordamos o processo de produção do espaço das ocupaçóes a partir do cotidiano vivido. A quinta sessão apresenta a discussão sobre a propriedade comum da terra nas ocupaçóes, e a sexta, a seu turno, demonstra de que modo o espaço abstrato se reafirma dentro do experimento radical da ocupação. Finalmente, as consideraçóes finais desenvolvem a ideia de uma prática espacial intermediária delineada como mediação concreta e movente que parte do espaço abstrato na direção do espaço diferencial.

\section{A PRODUÇÃO DO ESPAÇO: DO ABSTRATO AO DIFERENCIAL}

É n’A produção do espaço, de 1974, que Lefebvre formula com maior ousadia as suas teses relativas à problemática espacial, sua complexa e abrangente teoria do espaço social. A partir da economia política, o autor enuncia a produção do espaço como conceito teórico e realidade prática, aspectos esses indissoluvelmente ligados. O autor propóe aí uma modificação profunda na maneira de compreender o espaço

3 É fundamental para a nossa discussão que se reconheça o papel do método dialético no pensamento lefebvriano (MARTINS, 1996). Os temas, preocupações, embates teóricos e políticos, assim como o método de realização da pesquisa são orientados pelo método dialético hegeliano-marxista. 0 pensamento dialético tem, entre suas características, 0 reconhecimento do caráter contraditório da realidade. Nesse sentido, não se compreende a realidade extirpando-se as suas contradições, sob pena de se construir um saber marcado pela unilateralidade e - o que é pior - pela ideologia. A contradição é constitutiva do real. Das contradições, internas e inerentes ao ser social e histórico, provém o movimento que caracteriza o mundo como devir e não como coisa estática. A dialética como método de pesquisa requer a consideração constante do negativo e da contradição. Esse princípio cria diversos desafios, entre os quais a limitação da própria linguagem para expressar realidades que se contradizem internamente. No nosso próprio exercício, tentamos seguir as indicações metodológicas de Lefebvre (1975), sem, com isso, assumir um "estilo de escrita lefebvriano", tampouco tentar a redução -extrapolação do método ao modelo. Não se ignora nenhum dos dois riscos, mas não se esposa nenhum deles como projeto: antes, nossa tentativa é empreender uma pesquisa concreta pautada pelo método dialético, tal qual Lefebvre propôs. 
como realidade empírica e como categoria de análise. Trata-se de passar dos produtos (descritos, enumerados) à compreensão da produção: o espaço (social) é um produto (social) e não uma coleção de coisas e objetos (espaço físico) ou um receptáculo vazio e inerte a ser preenchido (espaço mental). A produçáo do espaço religa e coordena os aspectos da prática espacial.

Para Lefebvre, o capitalismo só conseguiu atenuar suas contradiçôes internas e sobreviver graças à sua permanente expansão e à passagem da produção de coisas no espaço à produçáo do próprio espaço. Nesse sentido, pode-se dizer que a produção do espaço está intimamente ligada à reprodução do modo de produção capitalista, englobando os níveis da reprodução bio-fisiológica familiar, da reprodução da força de trabalho e da reprodução ampliada das relaçôes sociais de produção.

O espaço abstrato, em Lefebvre (2000), corresponde à expressão espacial do trabalho tornado abstrato pela produção capitalista sob o controle do Estado moderno. O espaço abstrato, formal e quantificado, é simultaneamente homogêneo (o que vai na direção da negação das diferenças, sem, contudo, jamais eliminá-las por completo), fragmentado (pulverizado pela propriedade privada, funcionalmente segregado) e hierarquizado (organizado em termos de relaçôes centro-periferia de dominação). Ocupado, controlado e orientado para a reprodução das relaçôes sociais de produção, ele consolida uma lógica burocrática de controle e repetição. Espraia-se, portanto, por todo o planeta, negando as diferenças espaciais: as que provêm da natureza e da história, assim como aquelas originárias do corpo, das idades, dos sexos, das etnias.

Como amplamente reafirmado nos estudos urbanos e na geografia humana das últimas décadas (SOJA, 1993), o espaço não se situa no capitalismo como lugar passivo das relaçóes sociais, mas se revela ativo (operatório e instrumental) ao exercício das hegemonias. Evidentemente político e estratégico, ele é um meio de produçáo e de controle, mas que escapa parcialmente aos que dele se servem, aos que o engendram (o capital, o Estado). Isso se deve ao fato de que mesmo o espaço abstrato contém também suas contradiçóes internas (entre quantidade e qualidade; globalidade e fragmentação; homogeneidade e diferença; entre o que é concebido e o que é vivido).

No entanto, em meio a essas contradiçôes dos espaços, Lefebvre (2009) chama a atenção para a importância de novos movimentos sociais, não mais restritos às demandas em torno do mundo do trabalho, que questionam o uso e a organização capitalista do espaço, atentos às problemáticas da reprodução social e da vida cotidiana. Tais movimentos urbanos mostram que o espaço não é apenas econômico e subordinado ao valor de troca, e que tampouco é meramente um instrumento político homogeneizante. Diversamente, tal qual o tempo, o espaço é um protótipo perpétuo do valor de uso que resiste à generalizaçáo do valor de troca e do trabalho sob o capitalismo. Ainda que não tenham o caráter contínuo e institucionalizado do trabalhismo, a pressão desses movimentos aponta para a explosão de todos os espaços impostos, para a produção de um espaço autogerido pelos "interessados".

O espaço diferencial teorizado por Lefebvre é o espaço engendrado pelas contradiçóes do espaço abstrato, e, portanto, decorre da dissolução de relaçóes sociais orientadas pela homogeneização, fragmentação e hierarquização de objetos e sujeitos abstratos, e que implica no nascimento de novas relaçóes sociais, radicadas no uso dos espaços e nas suas qualidades múltiplas. O espaço diferencial significa também o fim da propriedade privada do espaço e da sua dominação política pelo Estado. Sua produção acontece a partir da completa imbricação entre uma vida cotidiana profundamente transformada 
e uma prática da diferença espacial. O espaço diferencial “[...] religará o que o espaço abstrato separa: as funçôes, os elementos e momentos da prática social” (LEFEBVRE, 2000, p. 64, tradução nossa). Esse espaço surge de um contraprojeto e visa a restituir os diferentes usos possíveis do espaço, isto é, a possibilitar a apropriação espacial contra a homogeneização patogênica de um espaço racionalizado, coercitivo, hierárquico, comandado pela lógica capitalista e estatal. Momento em que o corpo inteiro - restituído à condiçấo de totalidade - assume o protagonismo das invençôes.

Entre o espaço abstrato e o diferencial, habitam as práticas espaciais do desvio (détour), termo compartilhado por Lefebvre e pela Internacional Situacionista: "Acerca do desvio, já se sabe que deve ser estudado como prática intermediária entre a dominação e a apropriação, entre a troca e o uso. Opô-lo à produção ou dissociá-lo dela é desconhecer seu sentido" (LEFEBVRE, 2000, p. 425, tradução nossa). O desvio pode estimular diferentes aprendizagens sobre a produção de outras cidades e urbanidades possíveis. Experiências e práticas orientadas pelo uso do espaço, as quais explicitam tensôes contidas nas concepçóes espaciais dominadas pela mercantilização da vida.

Ao propor a distinção entre desvio e apropriação, Lefebvre persegue com rigor e cuidado o projeto de "mudar a vida, mudar a sociedade", orientando a reflexão para a assimilação dos erros e acertos das comunidades políticas, efêmeras ou duradouras, que já tentaram inventar uma "vida nova" por meio de um "espaço novo". Ao longo da história do espaço, os exemplos são muitos, assim como os impedimentos.

Para Lefebvre, a real apropriação do espaço envolve uma invenção morfológica, isto é, uma nova forma intimamente ligada às novas funçôes e às estruturas do prazer e da alegria. O desvio de um espaço pode ser bastante profícuo à concepção de um contraponto às formas de dominação instituídas. Contudo, ele será realmente apropriado quando realizar outras formas e estruturas arquitetônicas, urbanísticas e territoriais. As novas ideias e representaçóes, bem como os valores e interesses novos, precisam vir inscritos com um processo criativo total, da criação de um espaço inteiro. O espaço diferencial requer a organização, a disposição dos elementos essenciais que compóem um corpo de outra maneira, tanto quanto necessita de outras estéticas.

O urbano contemporâneo é repleto de embrióes com potências criadoras de espaço diferencial, quando considerados em seu conjunto. Há uma tendência à produção de dinâmicas que buscam se afirmar, como outros modos de existência na metrópole e/ou como resistências diante de dinâmicas heterônomas que engendram situações repressoras e autoritárias das quais se busca emancipar. Essas buscas tendem a ocorrer em variaçôes que combinam elementos ligados a dois formatos de ação política espacial: ou por meio de métodos autonomistas, em fuga de espacialidades sociopolíticas abstratas e hegemônicas; ou por meio do confronto em busca de alteraçôes nas instituições estabelecidas.

\section{DA CORUMBIARA À TINA MARTINS: OCUPAÇÕES NA RMBH}

“O Brasil é uma terra sem gente e uma gente sem terra": noutra perspectiva teórico-política, Holston (2013) parte desse aforismo para capturar a negação do acesso à propriedade fundiária como um dos pilares históricos da constituição e reprodução do regime de cidadania desigual no país. Paula (2002) igualmente salientou o papel 
do acesso desigual à terra na desigualdade, no autoritarismo e na dependência na sociedade e economia brasileiras. Holston (2013) observa que o acesso restrito à propriedade da terra perpetua a extraordinária desigualdade de renda e riqueza e reproduz a ilegalidade como a norma de acesso pela tomada de posse, invasóes, ocupaçóes etc. para a maioria dos pobres urbanos.

No período recente de crescimento econômico (2004-2013), a produção do espaço urbano metropolitano no Brasil viveu um novo ciclo de expansão e valorização imobiliária. A RMBH vivenciou transformaçôes de seu espaço urbano ligadas a um forte dinamismo do mercado imobiliário. Houve aumento exponencial da quantidade de construçôes, lançamentos, transaçóes, além da busca por novas áreas de atuação por construtores e incorporadores, e elevação dos preços praticados. $\mathrm{O}$ processo incluiu tendências socioespaciais de gentrificação e financeirização do espaço urbano, transformando significativamente a metrópole (MAGALHÃES, TONUCCI FILHO; SILVA, 2011).

Soma-se a isso a omissão usual do poder público quanto a políticas habitacionais inclusivas, o que potencializou a ocorrência de lutas, também usuais no Brasil, pela moradia em outras vertentes. Em Belo Horizonte, o cenário político trouxe uma guinada conservadora na década de 2000, reforçando a luta, dessa vez, pelo surgimento de açôes e experiências que extrapolaram a agenda e o repertório dos movimentos pela moradia e pela reforma urbana. Inicia-se uma nova rodada de movimentos que inclui as ocupaçôes urbanas.

As ocupaçôes inscrevem-se nas tradiçôes de luta pela terra urbana no Brasil, mas são dotadas de características peculiares. Entre os aspectos que as distinguem está uma conjugação de diversos agentes. Famílias em luta pela terra e/ou pela moradia, movimentos sociais e políticos organizados, tanto antigos como novos, e, por outro lado, agentes políticos ligados a instituiçóes consolidadas - Igreja Católica, esferas do Estado (administração pública e poder judiciário, por ex.), educação pública superior (alunos e professores universitários). Especificamente em Belo Horizonte, a nova onda de movimentos urbanos é marcada pela ausência de vínculos com as gestóes municipais do ciclo sintonizado à plataforma da reforma urbana, o que provoca uma ruptura e um conflito com grupos anteriormente estruturados e que participaram de formas variadas do processo de gestão e planejamento urbano do município, inclusive de sua política habitacional.

Ainda em 1996, teve início em Belo Horizonte a experiência pioneira da Ocupaçáo Corumbiara, num terreno particular no Vale do Jatobá, na região do Barreiro. Organizada pela Liga Operária (LOP) e pelo Partido Comunista Revolucionário (PCR), ela assentou 379 famílias engajadas no Orçamento Participativo da Habitação $(\mathrm{OPH})$, mas sem perspectivas de adquirir moradia. Segundo Bedê (2005), desenvolveu-se aí uma forma de organização popular incomum na cidade, através da demarcação de lotes e vias, cercamento do terreno, vigilância constante e revista de visitantes. Nesse processo, surge o Movimento de Lutas nos Bairros e Favelas (MLB), vinculado ao PCR. A ocupação Corumbiara, atualmente regularizada e consolidada como Vila, representa, para Lourenço (2014), um "mito de fundação" para novas ocupaçôes urbanas organizadas.

Depois disso, as ocupaçôes cessaram em Belo Horizonte por, pelo menos, uma década, movimento arrefecido graças à institucionalizaçáo da política habitacional da Prefeitura Municipal de Belo Horizonte (PBH) e neutralização dos canais partici- 
pativos. Em 2006, aconteceu, no bairro Serra, a ocupação Caracol, primeira apoiada pelas Brigadas Populares em colaboração com grupos da Vila do Cafezal. Um grupo de famílias sem-teto ocupou um prédio de três pavimentos por três meses até seu despejo. Mesmo breve, a Caracol chamou a atenção dos movimentos críticos à política habitacional na capital.

No final de 2007, encerra-se a ocupação de prédios abandonados e os movimentos passam a discutir a ocupação de terrenos ociosos. A primeira delas, Camilo Torres, no Barreiro, acontece em fevereiro de 2008. A partir de então, as Brigadas Populares não mais participariam diretamente da organização de ocupaçôes verticais em edificaçôes abandonadas, em parte pelo desinteresse das famílias em ocupar imóveis nas regiôes Centro Sul e Pampulha, distante de suas relaçôes sociais e do padrão unifamiliar. Além disso, as ocupaçôes horizontais apresentavam maiores possibilidades de resistência e permanência (LOURENÇO, 2014; MAYER, 2015).

A discussão de alternativas de ação quanto à ligação entre moradia e geração de trabalho e renda levou à tentativa de implantar, em associação com o Movimento dos Trabalhadores Rurais Sem Terra (MST), ocupações de caráter misto: rural e urbano. A discussão inspirava-se em experiências do Movimento dos Trabalhadores Desempregados (MTD) no Rio Grande do Sul e do MST na Região Metropolitana de São Paulo. A ideia era que as ocupaçóes combinassem habitação e atividades agrícolas - e até de produção e serviços - em terrenos urbanos. Segundo Lourenço (2014), a proposta dividiu os militantes, pois muitos não acreditavam na sua factibilidade. Ainda assim, a ideia foi levada adiante, materializando-se na ocupaçáo Dandara (2009).

Dandara veio a ter um papel decisivo nas lutas por moradia em razão de sua visibilidade nacional e internacional. A ocupação deu-se em terreno particular no bairro Céu Azul, mantido vago por motivos especulativos, acumulando dívidas de Imposto Predial e Territorial Urbano (IPTU). Os lotes amplos propostos para agricultura tiveram que ser reduzidos diante da pressão por habitação, levando ao abandono do projeto original em prol do mais denso de ocupação. Formada originalmente por 150 famílias, abriga atualmente mais de 1.100 famílias (LOURENÇO, 2014). O sentido misto rural e urbano persistiu na implantação de uma horta comunitária, que não conseguiu êxito de fato, embora famílias tenham seguido cultivando hortas nos quintais. O processo da Dandara trouxe também uma inovação notável: a construção de um plano urbanístico desenvolvido colaborativamente por comunidade, urbanistas e outros técnicos.

Desde as experiências da Camilo Torres (2008) e Dandara (2009), muitas outras ocupaçôes sucederam-se em Belo Horizonte: Irmã Dorothy (2010), Zilah Sposito / Heleno Greco (2011), Eliana Silva (2012 - despejada), Eliana Silva II (2012), William Rosa (2013), Guarani Kaiowá (2013), Rosa Leão (2013), Jardim Vitória (2013 - despejada), Esperança (2013), Vitória (2013), Nelson Mandela (2013 - despejada), Nelson Mandela (2014), Professor Fábio Alves (2014), Paulo Freire (2015), Zezeu Ribeiro e Norma Lúcia (2015), Novo Horizonte (2015), dentre outras.

Camilo Torres, Irmã Dorothy e Eliana Silva, as três situadas em um mesmo vale circunscrito pela Av. Perimetral no Barreiro, ocuparam terrenos que haviam sido doados pelo Governo do Estado para uso industrial e que posteriormente foram vendidos para terceiros, sem cumprir a função econômica à qual a concessão estaria vinculada. Juntamente com a Dandara, as três ocupaçôes foram reconhecidas pela $\mathrm{PBH}$ como Áreas de Especial Interesse Social 2 (AEIS-2) durante a IV Conferência de Política 
Urbana de BH em 2014, mas aguardam a aprovação do novo Plano Diretor. As demais ocupaçôes seguem sob constante ameaça de despejo e sob negociação com poder público, Poder Judiciário e proprietários.

Um desdobramento recente do movimento das ocupaçôes está na Ocupação Tina Martins, em 2016. Diferente das ocupaçóes discutidas, Tina Martins não é ato de luta pela moradia. O Movimento de Mulheres Olga Benário ocupou um prédio que foi utilizado como restaurante universitário da UFMG. Reconduzindo a luta à área central da Capital, o movimento reivindica a transformação do prédio - sem uso há 10 anos - em Casa de Referência da Mulher. O movimento propóe atender demandas que o poder público não tem atendido: acolhimento de mulheres em situação de risco, prevenção à violência, empoderamento e emancipação feminina.

O padrão de ação na Tina Martins repetiu aquele da criação do Espaço Cultural Luís Estrela, ocupação que foi um desdobramento das ações de Junho de 2013. Durante as reuniôes da Assembleia Popular Horizontal, articularam-se movimentos culturais e políticos, organizando a ocupação de prédio público situado no bairro Santa Efigênia. Essa ação levou o princípio do "ocupar" além da luta pela moradia, em direçấo ao uso coletivo e cultural. A criação do Luís Estrela recoloca na área central de $\mathrm{BH}$ as lutas transferidas para as periferias desde a ocupação de imóveis em 2006. O local tem servido simultaneamente como suporte e como objeto de açôes colaborativas de grande vitalidade, articulando múltiplos militantes e simpatizantes de modo criativo.

Os movimentos de ocupação iniciaram-se em torno da moradia, e ela mantémse como seu núcleo. Porém, é uma luta que se enriquece e fortalece pela articulação com outros temas e que promove aprendizado e cooperação entre agentes de diferentes geraçôes, filiações e interesses. Ademais, são movimentos que tentam explicitamente uma construção que mescla arte e política, ativismo e festa; intencional ou intuitivamente aproximando cotidiano, produção e reprodução.

\section{ESPAÇO, COTIDIANO E POLÍTICA NAS OCUPAÇÕES}

No rescaldo da contracultura dos anos 1970, Lefebvre atentou-se ao fato de que faltava àquelas novas formas e tentativas de vida comunitária "uma invenção morfológica” (LEFEBVRE, 2000, p. 437, tradução nossa). Tantos grupos, utópicos, efêmeros ou duradouros, ousaram experimentar e, em meados daquela década, pareciam ter vivido o fim da sua experiência radical. Esse fim deveu-se, segundo Lefebvre, "à ausência de um espaço apropriado", no qual se pudesse levar ao limite a vivência daquilo que denominou "arquitetura do prazer e da alegria, da comunidade do uso dos bens da terra" (LEFEBVRE, 2000, p. 437, tradução nossa). Cinquenta anos passados, parece-nos possível afirmar que estamos mais uma vez diante de uma experiência radical em busca de novos modos de viver ancorados em laços comunitários. Dessa vez, não obstante, as ocupaçóes nos parecem ter dado um importante passo na direção de produzir um espaço apropriado.

Ao se analisar a ocupação como lugar próprio de ação política coletiva exercida num território concreto, é necessário descrever quais relaçôes de poder se evidenciam nesses territórios e o que as constitui. Formulando a questão em termos teóricos, é 
necessário perguntar pelos dispositivos de poder que ali se colocam em jogo, mobilizando campos de saber, modos de subjetivação e, sobretudo, inscrevendo-se como momento singular na história da luta por acesso ao solo urbano e, dessa vez, fortemente determinado pela formação social e cultura política do Brasil contemporâneo.

A ocupação é um ato de coragem: é uma atitude radical que nasce preocupada em resgatar a vida cotidiana da dominaçáo do espaço abstrato e na qual se coloca em curso um processo de tomada de consciência dos entraves da produção do espaço urbano. Tal consciência - a qual arriscaríamos chamar urbana - implica iniciativa e participação, mesmo que sejam meramente tentativas ou incompletas.

Há dois vetores no movimento político desses ocupantes: um orientado às formas de pressão externa das instituiçôes; outro voltado às formas internas de coesão capazes de tornar os moradores uma coletividade. No primeiro caso, a prática política refere-se ao exercício das lideranças que aglutinam o grupo e ao apoio de variados atores urbanos no enfrentamento à repressão e às tentativas de despejo e reintegraçáo de posse por parte de instituiçóes de governo, proprietários da terra e aparatos de Estado. No segundo caso, o esforço político dirige-se ao erguimento dos espaços comuns (creche, cozinha, biblioteca) que reforçam relaçôes de vizinhança, na medida em que exigem esforços cotidianos de cooperação e solidariedade, bem como emprego do tempo livre de cada um, de suas horas de descanso do trabalho, em prol de um objeto de demanda comum.

Nesses dois movimentos (a luta pelo reconhecimento externo e a construção da coesão interna), a questão do espaço está colocada em termos da relação de forças sociopolíticas, na qual as identidades individuais deixam de fazer sentido e assomam o comum constituído pela falta (a moradia, o espaço próprio de residência). Notase, aqui, um poder que circula e funciona horizontalmente em rede, com intensa capilaridade, com relaçóes inscritas nos pontos de interseção permitidos pelos ritmos das vidas dos residentes. Uma dinâmica socioespacial comum que consolida os laços entre moradores. São pessoas reunidas não por uma "propriedade", mas justamente por uma ausência que as convoca e mantém juntas para realizar um ofício comum (ESPOSITO, 2010): a construção do que é necessário, viável e possível para sua sobrevivência. Estar junto é palavra de ordem para estabelecer a permanência; reunião e presença são estratégias para pressionar os governos, ampliar os objetivos (a posse do terreno e, depois, o reconhecimento formal da habitação) e prolongar as formas cotidianas de mobilização.

A maioria das ocupaçôes é precedida por um longo período de planejamento, realizado entre movimentos sociais e futuros moradores. Durante essa fase, são definidas regras e posicionamentos para o cotidiano dos lugares recém-ocupados. Esse aspecto prático descortina uma dimensão desalienante de um cotidiano instituído intencionalmente. Tem sido tática das ocupaçôes o estabelecimento de espaços coletivos logo quando da entrada no terreno. Esses espaços são criados para atender demandas práticas e, às vezes, pontuais, que respondem à urgência da resistência, necessária principalmente nos primeiros meses da ocupação.

Um dos primeiros alvos do esforço coletivo é a construção de cozinha e creche comunitárias. Ambas são fundamentais à alimentação e garantem o bem-estar das crianças. Essas instalaçôes também desempenham papel na interação entre a ocupaçáo e a comunidade externa, apoiadores e vizinhança. Ali se estabelecem ou se fortalecem relaçóes de solidariedade, cooperação e apoio mútuo. 
A construção da creche na ocupação Eliana Silva ilustra as possibilidades desse esforço de construção e politização do cotidiano. A creche foi concebida e construída originalmente pelos moradores, para depois incorporar mudanças com um projeto arquitetônico feito em parceria com universidades. $\mathrm{O}$ caso mostra quáo longe podem ir a organização e a criação de visibilidade pelos movimentos e apoiadores, assim como aponta o aprendizado sobre essa colaboração interna e externa. Embora não seja um caso de êxito trivial, podemos fazer duas observaçóes sem ingenuidade.

Em primeiro lugar, que uma necessidade prosaica, como a creche, pode criar mobilizaçấo político-afetiva baseada no cotidiano. Longe da grandiloquência das disputas político-partidárias, necessidades corriqueiras impulsionam a criatividade institucional feita de baixo para cima. Em segundo lugar, a importância da ampliação dos objetos da açáo coletiva como meio de extensão e dilatação no tempo e no espaço da coletividade. Há, nessa estratégia, um contraprojeto ao apelo desmobilizador do cotidiano privatizado. Se a conquista da moradia e o menor risco de despejo desmobilizam a comunidade, é necessário recriar crescentemente o envolvimento comunitário. Se isso for efetivo, o desejo de construção coletiva mantém-se, e a ampliação dos objetivos coletivos fortalece a ação política. Esse esquema diz respeito a um lema lefebvriano: mudar a vida, mudar a sociedade, passa por revolucionar o espaço cotidiano.

A prioridade na construção de espaços comuns é uma estratégia que delimita cotidianos de partilha e consolidação de laços. Trata-se de uma política do cotidiano que se soma aos encontros e assembleias - frequentes no início da ocupação para deliberação conjunta dos principais problemas enfrentados no seu dia a dia, mas que se escasseiam quando ela se consolida. Também iniciativas como as hortas comunitárias, espaços de lazer, mutiróes de autoconstruçáo de moradias ou de outras instalações coletivas estabelecem novos momentos de ação conjunta para além daqueles iniciais da resistência.

Numa ocupação, o espaço não é uma localização ou um suporte inerte; ao contrário, é um meio pelo qual fluem energias potenciais de mudança coletiva, configurando-se em espaço desviado, cujos usos se dão segundo táticas de apropriação diversas e divergentes da ordem abstrata do espaço, que se firmam como práticas contestatórias.

Se pensarmos nos habitantes de uma ocupaçáo enquanto subjetividades que se constituem em torno de objetivos ou contextos de ação mais ou menos definidos, compreendemos que sua ação conjunta é capaz de fornecer um ambiente de aprendizado político que transcende as possibilidades detidas pelos indivíduos no contexto anterior à ação conjunta. É distintivo da constituição de uma comunidade que seus membros carreguem para dentro da nova tessitura experiências peculiares que enriquecem um patrimônio emergente.

Pode-se opor a esse argumento o fato de que não há especificidade em tais tipos de comunidade, pois suas características seriam as que se verifica em qualquer situaçáo de reuniáo e açáo social. Ocorre que delimitar esse padrão de ação nas ocupaçôes e entendê-lo em sua especificidade nos habilita a capturar e reproduzir um aprendizado que provém da ação coletiva específica nessas comunidades. Tal aprendizado acontece na dimensão política e também como aprendizado social amplo, e, em especial, considerando as situaçóes de cidadania constrangida características das sociedades periféricas.

Dizíamos que a luta pelo direito à moradia e à cidade aproxima e catalisa a 
cooperação e o aprendizado entre agentes diversos. A vida cotidiana dessas ocupaçôes constitui-se tanto como luta quanto como espaço físico e social onde emergem possibilidades de ação e criação bastante flexíveis. A urgência, diversidade e extensão dos problemas vividos e sua invisibilidade para o mercado e para o Estado, formas hegemônicas de atendimento às necessidades cotidianas, abrem portas para a colaboração social e o comprometimento político.

Certamente, a tentativa de resolução dos problemas cotidianos básicos partiu sempre dos próprios grupos excluídos. A autoconstrução e a luta histórica pela moradia nas favelas brasileiras são uma afirmação disso. A luta pela permanência, o improviso e a gambiarra são formas que essa luta assume. No entanto, uma das faces da exclusão é o acesso restrito à educação, ao treinamento formal e à absorção da técnica e organização modernos. Essa carência tradicionalmente é compensada com a improvisação, a adaptação e a resiliência, positiva e negativamente. Tudo isso confere à vida de grupos subalternos intensidade e criatividade reconhecidas.

Quando convergem para as ocupaçóes atores dotados de treinamento formal rarefeito nas periferias, há formação de uma potência criativa singular. Treinamento formal e capacidade de organização aproximam-se de um ambiente de experimentação e cooperação com um grau de horizontalidade peculiar. Essa horizontalidade deriva do conteúdo político das ocupaçóes onde os movimentos sociais se aproximam da luta popular pela moradia. Delimitada a ideia de comunidades de ação política, podem-se iluminar forças de emancipação e realização mais ampla da cidadania. É usual e verdadeiro ver no cotidiano a diluiçấo da cidadania. No caso das nossas sociedades periféricas, essa diluiçáo atinge os limites do constrangimento: o cotidiano constrange a prática da cidadania e o cidadáo exerce uma cidadania constrangida. A condição periférica, além do mais, é transescalar. As ocupaçóes estão em periferias urbanas da sociedade brasileira, a qual é, por sua vez, uma sociedade desigual e periférica ao sistema mundo capitalista.

Essa desigualdade se materializa em cidadania constrangida, seja do lado dos subalternos, seja do daqueles que, não vivendo a subalternidade, se aproximam dos que a vivem como militantes de movimentos sociais. No primeiro caso, a exclusão e a negação de voz e direitos associam-se à exclusão socioeconômica. No segundo caso, o distanciamento em relação ao universo prático e cultural característico da população de baixa renda traz ao sujeito o desconhecimento de problemas e possibilidades de resolução, a não ser pelos procedimentos tradicionalmente contidos nas políticas habitacionais brasileiras.

O ambiente das ocupaçôes cria experimentaçôes partilhadas em desenho urbano (marcação das ruas), infraestrutura urbana (TEVAPs), financiamento e implantação de serviços comunitários (Creche Tia Carminha), estabelecendo uma experiência densa (SILVA, 2015), onde se testam saberes mistos de técnicas codificadas e "saberes autoconstruídos” (MORADO NASCIMENTO, 2016). Os desdobramentos dessa relação enriquecem o repertório dos residentes nas ocupações e também o repertório dos próprios movimentos sociais.

Denominamos esse processo de "experiência densa" porque se trata de uma dinâmica que emerge da combinação de fatores e agentes sociais em ação, e que, não fosse a densidade do momento criado pelas ocupaçóes, não ocorreria a não ser de forma diluída no tempo e no espaço. 


\section{ENTRE O PRIVADO E O COMUM: PROPRIEDADE NAS OCUPAÇÕES}

As tentativas de implementar lotes coletivos ao invés do tradicional lote individual nas ocupaçôes Dandara, Eliana Silva e Guarani Kaiowá não foram muito bem sucedidas na avaliação de Lourenço (2014). Contudo, ele aponta que os lotes coletivos seriam benéficos em termos de economia de escala quanto aos custos infraestruturais. Em termos da criação de mais espaços coletivos para interação, a proposta sofreu importantes desafios e restriçóes: a necessidade premente de assentar as famílias que chegavam às ocupações, preconceitos contra formas mais coletivas de habitação e de arranjos de propriedade (especialmente devido à origem da maior parte das famílias, que viviam anteriormente em espaços superlotados), e a falta de tempo suficiente para discutir isso com as famílias.

Nada disso deveria surpreender, já que a propriedade privada e a ideologia da casa própria são estruturais na sociedade brasileira e cada vez mais reforçadas pelas políticas habitacionais. Como Holston (2013) notou, num país desigual, onde o acesso à propriedade fundiária foi sempre negado aos pobres, a ascensão pessoal ao status de proprietário, mesmo ilegalmente, é vista pela maioria da população como um passo na direção de se tornar um cidadão pleno, distanciado dos sem-propriedade.

Entretanto, precisamos considerar que, embora o lote individual seja usualmente adotado como principal arranjo espacial e proprietário das ocupaçóes, isso não significa que ele se enquadre imediatamente no modelo da propriedade privada individual: podem existir restriçóes para quem possua um lote numa ocupação, especialmente contra a mercantilizaçáo da terra, já que os lotes devem ser usados para uso residencial e não para fins especulativos ou lucro. Portanto, é importante ressaltar que propriedade individual não é imediatamente idêntica à propriedade privada, na

40 comum designa os bens, espaços e recursos (materiais e/ou imateriais) que são usados e geridos coletivamente por uma dada comunidade por meio de uma série de práticas e relações de compartiIhamento e reciprocidade, fora do âmbito do Estado e do mercado, da propriedade pública e privada. Nos dias de hoje, as práticas e conceitos do comum estão se fortalecendo em torno de um princípio político que suporta, ajuda a articular e reconhece a potência de uma pluralidade de lutas, resistências e experiências emancipatórias. Colocandose em oposição à racionalidade neoliberal que procura estender os imperativos do mercado e da propriedade privada a todas as esferas da vida, o comum delineia a construção de novas formas democráticas de produção e gestão de recursos compartilhados. Mais sobre o comum, ver Dardot e Laval (2015). medida em que, sob determinadas condiçôes, a primeira pode não significar direitos exclusivos, alienáveis e absolutos sobre a terra, mas baseia-se nas ideias de uso, posse, função social da propriedade e direito à moradia.

Trata-se de uma formulação distinta de propriedade, mais próxima do comum ${ }^{4}$ do que da forma-mercadoria, mas só sustentada através de alguma forma de controle exercido pelos movimentos sociais ou pelos próprios residentes. Uma imagem crucial, registrada na ocupação Irmã Dorothy, mostra um alerta interessante. Diz a placa: "Aqui não vende área. Sob (sic) pena de expulsão quem vender ou quem comprar”: eis uma tentativa de resistência à propriedade privada e à terra transformada em mercadoria.

Entretanto, caso as ocupaçôes sejam oficialmente reconhecidas e integradas à cidade (ou mesmo antes disso), elas podem também subordinar-se às dinâmicas do mercado imobiliário. As ocupações vivem, assim, uma forte contradição: enquanto os movimentos sociais e residentes aspiram a ser reconhecidos pelo Estado (e, portanto, não mais sujeitados a viver sob o risco do despejo), eles também reconhecem que essa entrada na "cidade formal" pode significar a perda de muitos dos projetos coletivos e dos arranjos de propriedade mais comuns que eram possíveis enquanto muitos estavam engajados na resistência e em experimentaçóes socioespaciais.

De acordo com Blomley (2004), enquanto as ocupaçóes são uma afronta extralegal ou mesmo ilegal à hegemonia da propriedade privada, seja como um argumento político contra a desigualdade ou como uma reivindicação coletiva à terra por necessidade, os ocupantes podem também reivindicar do Estado a sanção de direitos de propriedade privada no espaço ocupado. Com isso, não queremos sugerir que toda luta é luta pela 
propriedade: certamente, muitas dessas lutas por justiça espacial transformam as situaçôes concretas daquelas famílias muito pobres, procurando um lugar na cidade, e elas também transformam a consciência política daqueles que delas participam. Através das ocupaçóes, os pobres urbanos formulam, nos termos de Holston (2013), uma cidadania insurgente contra uma ordem socioespacial arraigada e profundamente desigualitária.

Desse modo, as ocupaçóes remetem a diferentes relaçóes na direção do comum não apenas por meio do fomento de muitas práticas e espaços comuns (as hortas coletivas, a autoconstrução de instalaçôes comunitárias, o desenho urbano participativo), mas também por reivindicaçóes mais coletivas à propriedade da terra, contra a mercantilização da terra associada ao espaço abstrato, que perturbam o modelo de propriedade privada plena. Gostaríamos de sugerir que alteraçóes em escalas mais amplas - como o reconhecimento formal de arranjos comunais de propriedade fundiária (urbana) pela lei, timidamente admitido nos dias de hoje no Brasil - poderiam transformar as lutas locais de cada ocupação particular, dando-lhes tanto um vocabulário de reivindicação quanto um repertório de alternativas mais claras além da dicotomia entre o público e o privado.

\section{O ESPAÇO ABSTRATO NAS OCUPAÇÕES}

Passadas as fases iniciais de conceber a ocupaçáo, tomar o terreno e erguer as casas, observa-se, no momento seguinte, a reemergência do espaço abstrato no formato de uma reação em série, através de dispositivos diversos e em grande medida de natureza indireta, ao afloramento de diferenças efetivas na produçáo do espaço. Essas dinâmicas surgem engendradas por agentes e poderes distintos, com uma capacidade significativa de disciplinar, controlar e diminuir potenciais efetivos de tais experiências se constituírem em seus próprios termos diferenciais, produzindo outras espacialidades, outras experiências urbanas e outras narrativas acerca do que constitui o urbano contemporâneo.

De fato, após sua fase inicial de planejamento, as ocupaçôes passam por um período de construçãa, luta e resistência contra as ameaças de despejo e de ação correspondente no âmbito do aparato jurídico do Estado. $\mathrm{O}$ ativismo jurídico, que se realiza como forma de garantir direitos às ocupaçóes, constitui uma das mais importantes especificidades do contexto atual, além do próprio planejamento territorial de algumas ocupaçóes por parte dos movimentos, visando, assim, a anular as eventuais remoçóes de famílias em processos futuros de urbanização e incorporação das áreas pelo Estado.

Ocupaçóes já nascem, inegavelmente, no terreno da disputa entre dois conjuntos de forças: germes do espaço diferencial e o espaço abstrato, que permite o nascimento efetivo somente daquilo que seja conformado à sua própria lógica. Considerando a enorme assimetria entre esses dois conjuntos, mesmo que não seja de forma abrupta e direta (como no caso da simples remoção de uma ocupação recém-efetivada), o grupo de agentes que conduzem os processos conformadores do denominado espaço abstrato demonstra ser capaz de (re)entrar em cena e (re)definir o teor das diversas disputas que surgem, em escalas diversas, com as espacialidades diferenciais emergentes.

Os vetores decorrentes dessa disputa assimétrica criam tendências, em muitas ocupações de Belo Horizonte, que conduzem à desvirtuação dessas experiências ao longo de sua maturação. Os agentes que têm promovido tal processo são variados. 
Camila Diniz Bastos é estudante de Arquitetura e Urbanismo da Universidade Federal de Minas Gerais (UFMG); militante e integrante do Movimento de Luta nos Bairros, Vilas e Favelas (MLB), do Movimento de Mulheres Olga Benário e da Casa de Referência da Mulher Tina Martins.

E-mail: cdinizbastos@gmail. com

Felipe Nunes Coelho Magalhães é graduado em Economia, mestre e doutor em Geografia pela Universidade Federal de Minas Gerais (UFMG); professor adjunto do Departamento de Geografia do Instituto de Geociências (IGC) da UFMG. E-mail:felmagalhaes@gmail. com

Guilherme Marinho Miranda é graduado em Economia pela Universidade Federal de Minas Gerais (UFMG); mestre em Geografia e Ciências Políticas pela Université Panthéon-Sorbonne (Paris1), França; doutorando em Geografia pela UFMG; tutor do Programa de Incentivo à Formação Docente do curso de Formação Intercultural de Educadores Indígenas (FIEI), da Faculdade de Educação (FaE) da UFMG.

E-mail: guimarinhom@ gmail.com
Um primeiro exemplo é o mercado imobiliário informal que surge nas ocupaçóes e ganha forças em alguns casos, apesar das tentativas de contenção ou regulação por parte de organizadores e/ou lideranças. Seu aquecimento promove o incremento e a mobilização da renda da terra dentro das ocupaçóes, alterando as relaçóes internas de poder, internalizando uma dinâmica imobiliária que, no limite, reconduz a lógicas de exclusão e segregação semelhantes àquelas que criaram a necessidade da própria ocupação.

Essas dinâmicas tensionam o funcionamento das ocupações, reenquadrando-as à lógica da cidade neoliberal da qual, de início, se tentava escapar de forma autônoma. Assim, essas dinâmicas atuam na direçáo da produção de novos ativos imobiliários, mesmo que temporariamente informais. Dentro da ocupação, o mercado imobiliário em expansão reconduz o cotidiano para a criaçáo e enraizamento de canais de extração de renda da terra através da produção do espaço. É óbvio, entretanto, que os movimentos organizados têm consciência desse processo e fazem dele uma possibilidade de aprendizado a partir do próprio percurso das experiências. Resta, contudo, um campo aberto em relação às (eventuais) tentativas de se atenuar tais forças que inserem um nexo de mercado interno às ocupaçôes e que correm contra seus sentidos políticos.

Outra situação crítica que emerge da experiência das ocupaçôes diz respeito à segurança pública e à convivência com atividades ilícitas. Na medida em que se constituem em contraposição ao Estado, as ocupaçóes costumam ser apresentadas ou até percebidas no senso comum como fontes de insegurança ou de ataque à dita ordem pública. Assim, as próprias formas convencionais de promoção de segurança pública pelo Estado tornam-se problemáticas nas tentativas de construção social autônoma por grupos sociais marcadamente subalternos. Um exemplo disso são as situaçôes criadas pela entrada de agentes do tráfico de entorpecentes, os quais se aproveitam, em algumas situaçóes de ausência de policiamento em certas ocupaçóes, criando relaçôes de poder autoritárias sobre o cotidiano e os sentidos do lugar, relaçóes estas que enfraquecem a mobilização política e mesmo o próprio ato de ocupar.

Em suma, tais manifestaçóes próprias do espaço abstrato frequentemente têm a capacidade de anular impulsos emancipatórios suscitados pela diferença e pelo espaço diferencial. Elas insulam-se nas limitações e exploram fraquezas próprias de experiências embrionárias, impondo-se em função de seu caráter já consolidado como agrupamento de forças hegemônicas que se fazem presentes nesses espaços em construção. Enquanto poderes constituídos e forças hegemônicas, tendem a atuar na direção de sua própria reprodução e crescimento, mirando, para tal, inclusive na direção daquilo que busca escapar das relaçóes heterônomas e contradiçóes que tais poderes engendram.

\section{CONSIDERAÇÕES FINAIS}

A experiência da produção do espaço nas ocupaçôes urbanas de Belo Horizonte traz à tona um conjunto de elementos novos para a discussáo das relaçóes entre prática e aprendizagem, dominação, desvio e apropriaçáo do espaço. Oferece também estímulo a quem quer aprofundar o debate aberto por Henri Lefebvre acerca da emergência do espaço diferencial em meio às contradições do espaço abstrato vigente.

Respondendo à indagação sobre em que medida as ocupações engendram es- 
paços diferenciais, podemos afirmar que muitas das novas ocupaçóes constituem formas de urbanizaçấo tão mais singulares quanto mais sustentam experimentaçôes político-comunitárias em torno da produção do comum. Desse modo, elas atuam em direção diametralmente oposta à produção do espaço hegemônica na metrópole contemporânea - que tende ao cerceamento, à privatização, à constituição de espaços públicos onde se minimiza o elemento político conflitivo. No entanto, essas construçóes vivem em permanente disputa com as tendências mais pertinentes ao espaço social hegemônico da cidade neoliberal, que demonstram estar presentes nas ocupaçôes de formas diversas.

Diante dos obstáculos à realização de uma apropriação espacial efetivamente produtora de diferenças (para além daquelas induzidas), os sucessos e fracassos registrados pelas ocupaçóes urbanas levam-nos a pensar em modos de atualizar os sentidos concretos das açóes contra-hegemônicas, em outros espaços possíveis. Nesse contexto, cabe destacar a relevância dos desvios de funçóes dos espaços já existentes. Um processo de resistência à violência estatal e de tentativa de desprendimento da lógica da propriedade privada que passa, num primeiro momento, pela transformação dos espaços vividos.

Demonstra-se, no contexto contemporâneo de reorganização do cenário dos movimentos sociais urbanos no Brasil, a importância fundamental da ação direta localizada, e, ao mesmo tempo, sua insuficiência quando não inserida num mosaico mais amplo de estratégias voltadas para transformaçóes no plano das instituiçóes (como reconhecido plenamente por muitos dos próprios protagonistas dos movimentos organizados ligados às ocupaçóes). Conquistas muitas vezes restritas ao campo simbólico, mas que abrem brechas reais para a criação de uma realidade espacial diferente.

Isso nos leva a considerar, finalmente, a importância de aprendizados que produzam diferenças também em relação às formas e às estruturas espaciais. Mantendo o cuidado e o rigor dos apontamentos prático-teóricos de Lefebvre, precisamos pensar nos possíveis modos de as ocupaçôes entrelaçarem uma função, uma forma e uma estrutura do espaço diferencial. O que levaria os "interessados" nas ocupaçôes a (não) realizarem essa amarração? Com essa questão inconclusa, mas bastante estimuladora dos diálogos que constroem este texto, apontamos uma possível agenda de investigação futura sobre as potencialidades de espaço diferencial que entrevemos nas ocupaçôes belo-horizontinas.

Se podemos afirmar que as ocupaçóes são respostas concretas da população de baixa renda e dos movimentos sociais às contradiçóes do espaço abstrato da metrópole (particularmente à contradição entre a negação do acesso à terra e à moradia às classes trabalhadoras mais pauperizadas e a realidade de um imenso estoque de terrenos e imóveis ociosos mantidos para fins especulativos), disso náo decorre imediatamente, como se viu, que as ocupaçóes urbanas sejam o germe de um espaço diferencial.

Entretanto, o que aqui se quis apontar enquanto conclusão principal do artigo, a partir de uma lente lefebvriana, é que as ocupaçôes podem ser mais bem compreendidas em sua complexidade e diversidade como campos de tensão situados entre o espaço abstrato e o diferencial, contendo, contraditoriamente, tanto forças de dominação quanto de apropriaçáo, ora pendendo para um lado, ora para outro e, por vezes, constituindo-se não mais do que através de desvios. O que em si não reduz ou ignora suas potências associadas à produção de um espaço outro a partir de uma vida cotidiana diferente, orientada pelo valor de uso, através da apropriação: momento de fissura e irrupção na ordem da cidade capitalista.

\begin{abstract}
Harley Silva é graduado em História e Economia, mestre em Demografia e doutorando em Economia pela Universidade Federa de Minas Gerais (UFMG); professor do Curso de Arquitetura e Urbanismo do Centro Universitário Una.

E-mail: harley74@gmail.com
\end{abstract}

João Bosco Moura Tonucci Filho é graduado em Economia pela Universidade Federal de Minas Gerais (UFMG); mestre em Arquitetura e Urbanismo pela Universidade de São Paulo (USP); doutorando em Geografia pela UFMG; pesquisador no Centro de Desenvolvimento e Planejamento Regional (Cedeplar) da UFMG.

E-mail: jontonucci@gmail. com

Mariana de Moura Cruz é graduada em Arquitetura e Urbanismo pela Universidade Federal de Minas Gerais (UFMG); mestra em Urbanismo pela École Nationale Supérieure d'Architecture de Paris La Villette (ENSAPLV), França; doutoranda em Arquitetura e Urbanismo na Escola de Arquitetura da UFMG; pesquisadora no Centro de Desenvolvimento e Planejamento Regional (Cedeplar) da UFMG.

E-mail: marimoura.arq@ gmail.com

Rita de Cássia Lucena Velloso é graduada em Arquitetura e Urbanismo, mestra e doutora em Filosofia pela Universidade Federal de Minas Gerais (UFMG); professora adjunta na Escola de Arquitetura (EA) da UFMG.

E-mail:rritavelloso@gmail. com

Artigo recebido em 19 de setembro de 2016 e aprovado para publicação em 28 de março de 2017. 


\section{REFERÊNCIAS}

BEDÊ, M. C. Trajetória da formulação e implantação da Política Habitacional de Belo Horizonte na gestão da Frente BH Popular - 1993/1996. 2005. 302 f. Dissertação (Mestrado em Geografia) - Instituto de Geociências, Universidade Federal de Minas Gerais, Belo Horizonte, 2005. Disponível em: <http://www.bibliotecadigital.ufmg.br/ dspace/handle/1843/MPBB-6YGLGE>. Acesso em: 4 abr. 2017.

BLOMLEY, N. K. Unsettling the city: urban land and the politics of property. Londres: Routledge, 2004

DARDOT, P.; LAVAL, C. Común: ensayo sobre la revolución en el siglo XXI. Barcelona: Editorial Gedisa, 2015.

ESPOSITO, R. Communitas: the origin and destiny of community. Stanford, California: Stanford University Press, 2010.

FREITAS, L. F. V. Do Pro-Favela à Izidora: a luta pelo direito à cidade em Belo Horizonte. 2015. 245 f. Dissertação (Mestrado em Direito) - Faculdade de Direito, Universidade Federal de Minas Gerais, Belo Horizonte, 2015. Disponível em: <http://www.bibliotecadigital. ufmg.br/dspace/handle/1843/BUOS-A3XHVA>. Acesso em: 4 abr. 2017.

HOLSTON, J. Cidadania insurgente: disjunçóes da democracia e da modernidade no Brasil. São Paulo: Cia. das Letras, 2013.

LEFEBVRE, H. Lógica formal, lógica dialética. Rio de Janeiro: Civilização Brasileira, 1975. La production de l'espace. Paris: Anthropos, 2000 [1974]. Space: social product and use value. In: BRENNER, N.; ELDEN, S. State, space, world: selected essays. Minneapolis, London: University of Minnesota Press, 2009. p. 185-195.

LIBÂNIO, C. (Org.). Favelas e periferias metropolitanas: exclusão, resistência, cultura e potência. Belo Horizonte: Favela é Isso Aí, 2016.

LOURENÇO, T. C. B. Cidade ocupada. 2014. Dissertação (Mestrado em Arquitetura e Urbanismo) - Escola de Arquitetura, Universidade Federal de Minas Gerais, Belo Horizonte, 2014. Disponível em: <http://www.bibliotecadigital.ufmg.br/dspace/ handle/1843/BUOS-9QRGL5>. Acesso em: 4 abr. 2017.

MAGALHÃES, F.; TONUCCI FILHO, J.; SILVA, H. Valorização imobiliária e produção do espaço: novas frentes na RMBH. In: MENDONÇA, J.; COSTA, H. S. (Org.). Estado e capital imobiliário: convergências atuais na produção do espaço urbano brasileiro. Belo Horizonte: C/Arte, 2011. p. 17-40.

MARTINS, J. S. Henri Lefebure e o retorno à dialética. São Paulo: Hucitec, 1996.

MAYER, J. O comum no horizonte da metrópole biopolitica. 2015. 290 f. Dissertação (Mestrado em Arquitetura e Urbanismo) - Escola de Arquitetura, Universidade Federal de Minas Gerais, Belo Horizonte, 2015. Disponível em: <http://www.bibliotecadigital.ufmg. br/dspace/bitstream/handle/1843/MMMD-A7TP7N/dissertacao_joviano.pdf?sequence $=1>$. Acesso em: 4 abr. 2017.

MORADO NASCIMENTO, D. Outra lógica da prática. In: construídos. Belo Horizonte; Associação Imagem Comunitária, 2016. (Org.). Saberes [auto] _; LIBÂNIO, C. (Org.). Ocupaçôes urbanas na Região Metropolitana de Belo Horizonte. Belo Horizonte: Favela é Isso Aí, 2016.

PAULA, J. A. O mercado e o mercado interno no Brasil: conceito e história. Em: História Econômica \& História de Empresas, v. 5, n. 1, p. 7-39, 2002.

SILVA, H. Cidades, urbanização, desenvolvimento na Amazônia: notas para uma interpretaçáo lefebvriana. In: COSTA, G. M.; COSTA, H. S. M.; MONTE-MÓR, R. L. M. (Org.). Teorias e práticas urbanas: condiçóes para a sociedade urbana. Belo Horizonte: C/Arte, 2015. p. 317-342.

SOJA, E. Geografias pós-modernas: a reafirmação do espaço na teoria social crítica. Rio de Janeiro: Jorge Zahar, 1993. 